\title{
The Effect of Nonmarket Capabilities on Firm Performance: How Knowledge and Capabilities Accumulated from Nonmarket Arenas Contribute to Firm Performance
}

\author{
Cosmina Lelia Voinea ${ }^{1} \&$ Magdelijn Emaus ${ }^{2}$ \\ ${ }^{1}$ Faculty of Management, Science, and Technology; Open University; P.O. Box 2960, 6401DL Heerlen, The \\ Netherlands \\ ${ }^{2}$ Manager Digital \& Mobility Delivery; Accenture; Amsterdam, The Netherlands \\ Correspondence: Cosmina Lelia Voinea, Faculty of Management, Science, and Technology; Open University; \\ P.O. Box 2960, 6401DL Heerlen, The Netherlands.
}

Received: August 17, 2017

Accepted: November 20, 2017

Online Published: November 23, 2017

doi:10.5539/ibr.v11n1p1

URL: https://doi.org/10.5539/ibr.v11n1p1

\begin{abstract}
This study addresses the existing gap in the nonmarket literature vis-à-vis nonmarket performance effects and the demand for managerial tools to obtain, sustain and transform knowledge of various nonmarket activities into specific nonmarket assets. This paper aims to describe the various nonmarket arenas and to explain how knowledge and capabilities accumulated from different nonmarket arenas contribute to firm performance.
\end{abstract}

Keywords: nonmarket, dynamic capabilities, political context, legal setting, social environment, firm performance

\section{Introduction}

Due to globalization the scope of competition is shifting from the country level towards the global level (Frynas, Mellahi and Pigman, 2006, p341), firms increasingly need to possess a certain degree of flexibility in order to remain competitive in a global arena. Success in the $21^{\text {st }}$ century organization will depend, according to Hitt, Keat and Demarie (1998) firstly on building strategic flexibility and stress for the need for an organizational culture oriented towards learning and innovation. This is especially important for multinational enterprises (MNE's) that are affected by globalization at different levels, such as the country level, industry level and the global level (Govindarajan \& Gupta, 2000). Increasingly, literature is focused towards nonmarket actions and competences as a means to complement market strategies, since many nonmarket issues arise from market activity (Baron, 1995a, p55). Baron highlights the relevance of effectively dealing with go vernments, interest groups, activists and public issues, related to over traditional market strategies targeting operational efficiency, internal organization, supply chain management, distribution channels and alliance networks. He describes the nonmarket environment as consisting of social, political, and legal arrangements that structure interactions among companies and their public, dividing a corporate strategy into a competitive (market) and public (nonmarket) component (Baron, 1995a; Baron; 1995b; Baron, 2003). This has lead to the rise of a new subject in strategic literature concerning the implementation and effect of nonmarket strategies. Several authors have since then advocated and -to a lesser degree- demonstrated the favorable outcome of nonmarket strategies.

Shaffer, Quasney and Grimm (2000) were the first to provide empiric evidence on the effectiveness of nonmarket strategies and their implications on firm level performance. They observe that that the greater the number of nonmarket actions, the better the firm performance, differentiating them from an increase in market actions which had no significant effect on firm performance. However, their study was limited to government directed actions and thus excluded other political, legal and social nonmarket actions.

$\mathrm{Ma}$ (2004) is one of the first to broaden the scope of the use of nonmarket actions, by linking this usage to a more global corporate competitive advantage. Distinguishing his theory from previous authors, Ma (2004) suggests that a nonmarket strategy should not focus merely on corporate political actions. This strategy of 'co-option' is defined as containing "different types of nonmarket actions and [attempting] to align other parties' interest with that of the focal firm, providing possible competitive advantages by opening windows of opportunities, removing external obstacles or neutralizing threats" (p917). Put differently, various types of 
nonmarket actions are proposed here to act as a coherent tool, enhancing the firm's overall competitive advantage.

Subsequent recent literature supports the theory that the use of nonmarket strategies can reduce costs and provide ample additional benefits. Thus, the current body of empiric evidence on the use and effectiveness of nonmarket strategies is promising, yet lacks clarity on which nonmarket actions transcend regional, national and institutional nonmarket boundaries which could be captured and developed into a corporate nonmarket capability. In other words, a holistic approach towards nonmarket strategies is yet absent.

In pursuance of a more conceptual notion of what the political nonmarket comprehends, Dahan (2005) has attempted to ameliorate the current classification of political resources that are used in corporate political action. He criticizes the present literature categorization of resources for their 1) lack of external dimensions that are taken into account, 2) lack of distinction between image and reputation, 3) lack of exactitude on the definition of the areas of expertise that CPA demands, 4) the collective nature of specific resources and thus their congruence with other nonmarket arenas and 5) their incompleteness in disregarding the organizational skills required for certain CPA events (2005, p45-47). This thesis attempts to expand Dahan's (2005) classification of political resources specifically by paying attention to his third and fourth critique, by defining and combining multiple nonmarket arenas together. In this way, this study fills in the gap by investigating the contribution of nonmarket actions from all three arenas on the development of nonmarket assets that improve firm performance. I argue that multinationals and foreign owned firms can learn from their multiple subsidiaries and potentially use this knowledge to enhance firm performance, which is supported by learning theories (Argyris \& Schön, 1978; Argyris, 1977; March et al., 1991) and promising empiric evidence from the successful development of corporate alliance capabilities (Kale \& Singh, 2007).

Therefore, the existing gap in the nonmarket literature and demand for managerial tools to obtain, sustain and transform knowledge of various nonmarket activities into specific nonmarket assets. This paper aims to describe the various nonmarket arenas that multinationals can operate in and to explain how knowledge and capabilities accumulated from these different arenas affect firm performance. To this day, the literature supporting the use of nonmarket strategies is unilateral, only providing evidence for specific nonmarket actions (Hillman, Keim \& Schulder, 2004). In doing so, short-term positive effects of nonmarket actions on firm performance have been described on one dimension or industry, yet little attention has been given to a more constructive, long-term nonmarket strategy. An obvious plea exists for future research including capabilities (Bonardi, Jillman \& Keim, 2005; Bonardi, Holburn \& Vanden Berg, 2006; Frynas et al., 2006). Apart from the lack of consensus on how to distinguish nonmarket actions, another -more conceptual- issue arises in literature supporting the positive relation between nonmarket actions and firm performance. Often, all market-actions are given equal weight in the analysis (Schaffer et al. 2000; Usero \& Fernández, 2009), which rules out the possibility to measure which nonmarket actions account for the largest change in firm performance. In our endeavor to ans wer the question of how can the knowledge and capabilities accumulated from different nonmarket arenas contribute to firm performance? This paper attempts to contribute to the field of strategy by commencing the identification of the potential building blocks of a corporate nonmarket capability. By using a PLS technique, the weight that each indicator -in this case nonmarket actions- has on building certain nonmarket assets that influence firm performance, will be analyzed for the first time. This results in a valuable contribution to the field and facilitates future research on capability building and application.

\section{Theoretical Framework}

In the field of research on the nonmarket environment, many new insights have been gained in the last two decades. Given the immaturity of the field, the majority of academic literature in this discipline is still focused on finding empiric evidence for the assumed effectiveness of isolated nonmarket actions on firm performance. Other studies report about the use of nonmarket strategies and their position with respect to market dynamics. Thus, in current literature, either a contribution to the content and function of nonmarket actions is given, or a proliferation to nonmarket theories discussing the appropriate form of nonmarket actions is provided. In order to help explain the development of nonmarket assets, all potential facets of the various nonmarket arenas must be taken into account. Consequently, we argue the need for the construction of a bridge between short-term nonmarket actions and a constructive path towards the development of nonmarket assets.

In this section, an overview of the present literature is provided, uniting the various aspects of the current debate on the use and effectiveness of nonmarket actions. Firstly, we discuss how multinational firms could merit from the development of nonmarket assets is discussed. Subsequently a rationale is given as to why such assets provide opportunities for foreign owned firms in particular. Next, the function of nonmarket actions according to 
Baron (1995a) and supplementary findings since then are discussed. Parallel to this overview, the various nonmarket arenas and their corresponding actions are set out in order to describe the measurement model of the PLS. This leads to three hypotheses supporting the main research question, who together describe the structural model. Finally, both models are combined and the overall conceptual model of this study is presented.

\subsection{Linking Nonmarket Assets to Performance}

Many studies have focused on the effectiveness of integrated strategies. This is supported by the extensive and ever growing literature advocating the integration of market with nonmarket strategies (Baron, 1995a; Baron 1995b; Baron, 1998; Bonardi et al., 2006; Levy \& Egan, 2003; Ma, 2004; Frynas et al., 2006; Shaffer et al., 2000). Although research up until now has primarily focused on these integrated strategies, some have been able to isolate the effect of nonmarket actions themselves.

Shaffer et al. (2000) were the first to report the positive and significant effect of nonmarket actions on firm performance, in which profit was measured by market share, profits and capacity utilization (Shaffer et al., 2000, p137). Interestingly, they found the number of market actions to be unrelated to firm performance, whereas the number of nonmarket actions did positively affect firm performance. Despite the fact that their research was limited to nonmarket operations acted out by governmental institutions, the study provides significant evidence for the positive effect of nonmarket action on firm performance.

Even though 'the study of business political action [...] is a field rich with nearly inexhaustible opportunities' (Windsor, 2001, p384) I argue that in perpetrating mere political agreements, the field of nonmarket dynamics has only begun to understand the possible welfares that conscious endeavors in the nonmarket environment can offer. In consequently disregarding the social, legal and cultural benefits that can be reaped from other types of nonmarket actions, valuable nonmarket assets either directly or indirectly enhancing firm performance are overlooked.

For instance, Tian \& Gao (2006) address the issue of organizational legitimacy and the way nonmarket strategies can have a large influence on them. The authors state that when organizational legitimacy is absent, "the ability of the firm to pursue its goals and accumulate resources can be substantially reduced" (p101). This identifies a link between nonmarket actions and performance in the sense that they can not only enhance performance, but also help prevent a decline in performance.

In addition to that, Clougherty (2003) proved that nonmarket actions and strategies can influence the outcome of merger reviews and antitrust policy directly affecting firm performance. These outcomes derived by nonmarket action, directly affect a firm's market activities and can therefore substantially influence firm performance. Others also describe a similar positive effect of nonmarket actions on firm performance by employing corporate political action (Bonardi et al., 2005; Blumentritt \& Nigh, 2002).

Finally, Usero \& Fernández (2009) found an interesting dissimilarity in the effect on firm performance between market and nonmarket actions, equal to that of Shaffer et al (2000). Their study reveals that "followers in pursuit of eroding a competitor's first mover advantage by undertaking more market actions do not succeed in this abrasion. However, followers that take more nonmarket actions were successful at taking back market share from the pioneer" (Usero \& Fernández, 2009, p1139). Put differently, undertaking nonmarket actions was more successful in reducing a contender's first mover advantage than endeavoring to market actions. This finding authenticates a unique effect on firm performance solely due to the use of nonmarket actions that cannot be replicated or obtained by employing market actions. In this way, nonmarket actions can directly increase firm performance.

The abovementioned studies clearly empirically demonstrate the ability of isolated nonmarket actions to positively influence firm performance. Unfortunately, despite the acknowledgement by Baron (1995a, 1995b) and later Bodewyn (2003) that the scope of the nonmarket environment exceeds political actions, research on the effects on performance has mainly focused on the latter.

Several authors call for a coalescence of these various arenas, both conceptually as well as practically. The practical necessity is best described by Windsor (2001). He identifies the involvement of the public interest and business ethics as overarching dimensions to various disciplines that are targeted by the nonmarket environment, e.g. economics, political science, sociology and strategic management (2001, p403). Given this characteristic of the nonmarket environment, a holistic approach can provide new insights into the nonmarket environment that can result to the development of new tools that directly affect a firm's performance.

On a more conceptual note, Hillman et al. (2004) fuse corporate political action and corporate social performance, supporting the inevitable interconnectedness of all arenas in the nonmarket environment (Baron, 
1995a; Baron 1995b; Bodewyn, 2003). It is exactly this inevitable conceptual and practical integration that supports the call for a more integrative, holistic approach. The resource-based view (RBV) provides potential answers to this challenge, in the form of the dynamic capabilities perspective (Getz, 2001), which is discussed next.

Dynamic capabilities perspective

The dynamic capabilities perspective describes how competitive advantage is reached in a rapidly changing environment (Chandler, 1992; Kogut, 1994; Teece \& Pisano, 1994; Teece et al., 1997). The approach emphasizes the development of management capabilities and difficult-to-imitate combinations of organizational, functional and technological skills, emphasizing efficiency (Teece et al., 1997).

The below-mentioned definition of this approach is followed in this thesis, as it embodies the miscellaneous opportunities of the perspective. Yet, since no previous research has attempted to manifest a capability from empiric evidence, the focus lies of this thesis on the development of the building blocks of such a capability first. The characteristics necessary to validate a corporate dynamic capability are considered beyond the scope of this study. This results in the following definition:

'The term 'capabilities' emphasizes the key role of strategic management in appropriately adapting, integrating and reconfiguring internal and external organizational skills, resources, and functional competences to match the requirements of a changing environment.'(Teece et al., 1997, p515)

\subsection{Nonmarket Assets and Nonmarket Arenas}

According to Baron, the principal nonmarket capability that cannot be replicated and thereby provides a nonmarket advantage is "the knowledge, expertise, and skill of managers in addressing nonmarket issues" (1995a, p60-61). Thus, crucial to learning and building such a capability is to know which type of nonmarket actions aid to develop nonmarket assets that enhance firm performance. In order for these firm-specific nonmarket actions to be sustainable and positively contribute to firm performance, the assets and competences that are the cornerstones of this advantage must be difficult to imitate (Baron, 1995a, p60; Teece et al., 1997). Unfortunately, as illustrated before, current literature on the nonmarket environment remains in disagreement as to the how nonmarket actions and competences ought to be classified. A brief discussion of the current classification is presented here.

\section{Current nonmarket asset classifications}

Several authors have put forward different difficult-to-imitate latent concepts that underlie easily replicated market actions, such as scanning the environment and evaluating (political) markets and competitors (Teece \& Pisano, 1994; Baron 1995a; Baron, 1995b; Vining et al, 2005), choice (Baron, 1995a; Vining et al., 2005), quick reconfiguration (Teece \& Pisano, 1994), creating access and influence (Bodewyn, 2003; Ma, 2004), building a trustworthy reputation (Baron, 1995a; Dahan, 2005, Hemphil; 2006), coercion, cooperation and building moral commitment (Bodewyn, 2003), expertise, public image, recreational skill (Dahan, 2005) or stakeholder support (Dahan, 2005; Mahon et al., 2003).

These actions and capacities can then either be classified as offensive/defensive, domestic/international (Shaffer et al., 2000), access or ownership based (Schuler et al., 2002a; Ma, 2004), proactive/reactive, relational (long-term) or transactional (more ad hoc), according to the level of participation (alone or collectively), type of strategy (domestic/multi-domestic/global) (Hillman et al., 2004; Rodriguez et al., 2006), their process (technological, organizational or managerial) (Teece \& Pisano, 1994; Teece et al., 1997), be focused on interaction or pressure (Dahan, 2005), distinguished by subject such as information, financial or constituency building (Hillman \& Hitt, 1999) or by type of resource (financial, relational or organizational) (Dahan, 2005).

\section{Nonmarket arenas}

As stated by Baron (1995a), the environment of business is composed of market and nonmarket components, and any approach to strategy formulation must integrate both traditional market and nonmarket considerations in order to control a firm's opportunities. He argues that the nonmarket environment consists of social, political and legal agreements that structure interactions that are intermediated by the public, stakeholders, government, the media and public institutions (1995, p47).

Bodewyn (2003) who extensively discusses the nonmarket environment from various perspectives provides a more elaborate definition, which also adds culture as a fourth area of attention. Given the fact that an overarching nonmarket capability should contain all possible actions that can be employed by firms, his following definition of the nonmarket is also used in this thesis: 
Nonmarket refers to (a) values expressing the purposive pursuit of public interests; $(b)$ internal and external interchange mechanisms of coercion and cooperation that complement and balance competition in a reciprocal manner at various levels of interaction; (c) relationships among market and nonmarket organizations resting principally on their actors'sovereignty rights; and (d) the conflictual integration in the light of their failures of society's economic, political, social and cultural organizations.'(Bodewyn, 2003, p320).

In doing so, both Baron (1995a) as Bodewyn (2003) distinguish several areas of attention when acting in the nonmarket environment, demonstrating the complex nature of the nonmarket environment. It is mainly due to the fact of empirical challenges that the field of research on nonmarket actions has only recently begun to de velop a substantial body of work.

However, the vast body of this research has focused on the effects of political action and has left aside the legal, social and cultural arena. A rationale for why so many subsequent studies focused on the political side of the nonmarket, is tacitly provided by Windsor (2001). He points out the interconnectedness of political nonmarket actions in which they touch upon multiple arenas, simply due to their effect on several stakeholders and media, who in their turn often influence governmental institutions. He also refers to this as the problem of multidimensionality of political action' (Windsor, 2001, p385). Exactly which empiric evidence that advocates the effectiveness of nonmarket actions following Baron (1995a) and Bodewyn (2003) and which new insights have been generated since then, is discussed in the next section, according to their subdivision of the nonmarket of political, legal, social, and cultural related nonmarket activity.

Before proceeding to a specification of these nonmarket arenas, I would like to stress out that the nonmarket does not solely consist of political dynamics. Regarding social, cultural and legal effects of nonmarket activity as political effects can lead to misspecification of nonmarket dynamics. In turn, this reduces the opportunities that can be seized from exploiting them. Thus, in order to avoid political blinders, after discussing the vast body of work treating publications related to the political aspects of the nonmarket, attention is also given to the current research on legal, social or cultural nonmarket efforts. However, the immaturity of the field entails a lack of specific research on cultural nonmarket issues. The limited body of work that can be related to this latter arena is thus discussed together within the social nonmarket arena.

In the next sections, an attempt is made to construct a theoretical bridge between existing empiric evidence which ad hoc nonmarket actions positively influence firm performance, to those nonmarket actions that -in theory- create sustainable nonmarket assets.

\section{Political nonmarket arena}

Baron (1995a) characterizes the nonmarket environment by issues, interests, information and institutions. He constructs these different arenas as all imaginable "interactions that are intermediated by the public, stakeholders, government, the media and public institutions" (1995a, p 47). In the case of the political arena, Bodewyn (2003) expands this to actions that go beyond the scope of government. In this paragraph, several examples of political nonmarket action and assets are provided. However, a remark must be made that for conceptual reasons, governmental relations regarding legal issues (such as direct influence on litigation) are discussed in the legal arena.

The first group of political assets that arise from literature is those of having strong government relations. For instance, Frynas et al. (2005) find that government intervention and relations are crucial to the success of actions taken by both early as late movers (2005, p337). In order to understand the eclectic process of acquiring, sustaining and exploiting firm-specific political resources in an international context, they explore the causal relationship between political resources and first mover advantages. Interestingly, apart from re-affirming the presence and complexity of the relationship, the author's report that nonmarket activity can be used successfully both by first movers as well as late movers in neutralizing the success of the first mover. In this, they highlight the utmost importance of governmental relations.

A last group of political assets can be identified in the establishment of alliances and coalitions with other interest groups, in order to influence political issues (Hillman, 2003; Meznar \& Nigh, 1995; Yoffie and Bergenstein, 1985; Uzzi, 1997). Yoffie and Bergenstein were one of the first to identify the creation of coalitions with a wide array of firms and governmental officials as crucial in creating a political advantage (1985, p137). Uzzi (1997) then linked this to firm performance. According to him, socially embedded working relations (as supposed to ad hoc market relations) "facilitate troubleshooting" ( $p$ 47). He states that apart from having a positive effect on firm performance, these problem solving arrangement benefit the entire network, due to their contribution to an innovative and learning environment (1997, p47). Even though the nature of the 
argumentation of the author is from a social network perspective, I argue that the same reasoning applies for the establishment of partnerships dealing with political issues.

Altogether, these three groups of assets are found to be influential in creating political assets that in their turn have an influence on firm performance. This leads to the following hypothesis:

H1: Knowledge and benefits accumulated from actions in the political arena of the nonmarket environment explain the positive contribution of political assets to firm performance.

\section{Legal nonmarket arena}

Again, strangely, the body of literature discussingthe different nonmarket arenas does not mention a clear-cut definition of the various arenas. As mentioned previously, it is the political nonmarket arena that is elaborated on deeper and consequently conceptually more developed. Yet, the definition of a legal arena remains absent. Even Baron (1997) does not define either the legal or the political arena in his follow-up research on integrated strategies and international trade disputes. In this study, he clearly touches upon the subject of American law, entering the legal nonmarket arena.

The use of judicial strategies on nonmarket tactics in Asia is also mentioned by Aggarwal (2001). However, he does not provide a clear description of what these strategies should entail, nor does it clearly delineate the boundaries of the legal arena. Thus, due to a lack of available definition, all research reporting actions directly influencing any form of litigation or treating specific legal issues is discussed here.

Firstly, Baron (1997) reports the positive effects of an integrated strategy in the case of Kodak Company and Fuji Photofilm Company, in which he specifically addresses activities in the legal arena. He states that initiating trade actions, filing petitions and subsequently directing the public and congressional attention to the case results in a remarkable synergy between both market and nonmarket strategy. Meznar \& Nigh (1995) appoint se veral ways in which such buffering activities (in which a firm tries to control the external environment) can be undertaken. They mention the use of lobbyists to represent the firm's interests and using trade association(s) to exert influence on the legislative and regulatory processes (1995, p995).

Hillman (2003) suggests how the latter can be accomplished by using educational programs to train employees. This would be classified by Getz (1997) as a pressure-oriented legislative strategy, whereas the more information-based strategy contains the use of lobbyists. Hillman describes the process of lobbying as constituency building, in the way that influence on policy is sought through others (2003, p470).

The effectiveness of professional lobbying has merited great attention by Lord (2000). He found all actions taken to influence a legislator's public policy to be statistically instrumental; however, particular circumstances greatly determine the strength of this success $(2000, \mathrm{p} 90)$. This specific type of expertise calls for the use of external lobby experts - as supposed to training employees on the side.

Meznar \& Nigh (1995) also suggest working actively to reduce the level of government regulation affecting the firms activities. This protest can occur in two ways. It can occur before legislation has passed by alerting governments to the possible impacts of legislative scenarios of the firm (1995 p 995). Additionally, directing the public and congressional attention to current regulations as discussed earlier by Baron (1997), can also aid to lower the power of regulatory agencies affecting the firm.

Lastly, one of the most directly influencing nonmarket actions is participating in testimonies before hearings of government bodies (Hilman, 2003; Clougherty, 2003). As opposed to many other authors who combined market and nonmarket strategies in their studies, Clougerty (2003) was able to report an isolated effect of nonmarket strategies. Even though the author states that antitrust institutional independence plays a fundamental role in the effectiveness of corporate political actions (emphasis by myself), the unit of analysis of his research was the influence firms can have on the rulings of these anti-trust committees. This is why I argue this contribution should be considered legal, not political, given the required knowledge of the jurisdictional legislation. In his study, Clougherty (2003) demonstrates the influence that nonmarket actions can have on the outcome of merger reviews and antitrust policy. Consequently, exerting influence on these rulings directly influencing a firm's market activities can have a substantial impact on firm performance.

As to the effectiveness of legal nonmarket actions, a recent study by Usero \& Fernández (2009) reports that taking back market share from a pioneer by using legal nonmarket actions is found to be successful. Using market strategies however did not have any influence. Illustrations of these legal actions as mentioned by Usero \& Fernandez are lawsuits, filing complaints with regulatory bodies and making public accusations against rivals (2000, p 1140). These coincide with actions mentioned by other authors such as Meznar \& Nigh (1995) and Baron (1997). This all together leads to the following hypothesis regarding the development of assets in the legal arena: 
H2: Knowledge and benefits accumulated from actions in the legal arena of the nonmarket environment explain the positive contribution of legal assets to firm performance.

\section{Social nonmarket arena}

As to be expected, the same conceptual issue as encountered in defining the other arenas, arises when establishing the boundaries of a social nonmarket arena. Although ill defined, the public is given a leading role in social nonmarket actions and should therefore be considered a key identifier of the social nonmarket arena. For instance, Baron (1995a) distinguishes reputation as an important asset in the nonmarket environment. According to him, reputations are either (re)constructed or destroyed by actions (1995a, p62), which authenticates a theoretical connection between nonmarket actions, corporate social responsibility (CSR) and firm performance. CSR has been widely discussed in literature in the last decade and is considered $\mathrm{s}$ an important aspect of the nonmarket arena.

Hemphil (2006) is one of the first to roughly link CSR to firm performance. He describes the importance of balancing a firm's social reputation with the fiduciary responsibility to for instance shareholders. In doing so, the authors stress the need of "balancing a firm's long-term reputation with the short-term economic consequences of criminal and civil litigation over improper business practices" (2006, p635). In other words, the short-term financial responsibilities towards shareholders need to be properly evaluated with the long-term responsibilities towards all types of stakeholders. The authors surmise the effect of long-term reputational damage when continuously acting upon short-term issues. Conversely, having a more long-term focus can thus positively influence a firm's reputation as well as its performance, as theorized in this study.

Furthermore, Rodriguez et al. (2006) acknowledge the importance of the nonmarket environment for MNC's and put forward the conceptual difficulties in defining corporate social responsibility. More importantly, they propose an interesting demarcation between global CSR and country-specific CSR, in which they recognize the complex context that MNC's find themselves in as well as inadvertently advance the concept of the social characteristics of non-market assets. The identification of the social scope of these nonmarket actions provide valuable insights as to which building blocks could potentially create and sustain these nonmarket assets.

The fact that constructing a long-term reputation is culturally challenged is outlined by Tian \& Gao (2006). They discuss the differences between acquiring legitimacy in Chinese firms compared to the West. According to the authors, nonmarket actions can have a large influence on organizational legitimacy and, when absent, "the ability of the firm to pursue its goals and accumulate resources can be substantially reduced" (2006, p101). In this way, they indicate a difference in nonmarket approach on a cultural level, implying that identical nonmarket assets can have different (and even reversed) effects in different geographical areas. This is supported by evidence from He (2006). He indicates the nonmarket environment as key essential in making strategic decisions, in which he specifically points out of this in emerging settings such as China (2006, p360).

However, Kostova \& Zaheer (1999) offer a solution to this cultural challenge. They mention that organizations can de velop a competence in dealing with different institutional environments (1999, p68). According to them, the institutional distance mainly caused by cultural differences differs in every country. They assert that engaging relations and cooperating with institutions can help to decrease this distance. I argue that these relations can prove to be an influential tool in understanding the nonmarket environment in a particular country or region. This can result into more firm-specific nonmarket actions that are tailored to the situation at hand, improving the effectiveness of various types of (non)market actions.

Closely linked to an organization's legitimacy is its reputation. As discussed earlier, Uzzi (1997) discusses the way organizations can develop embedded ties within a network, constructing social arrangements and partnerships that help facilitate the processes in the market environment. This facilitation is surmised in timesavings due to a better understanding of each others business activities. Hence, these activities are more suitably adjusted to each other, a decrease in contract costs is reached due to the high level of trust and an increase in time to market. The author identifies nonmarket reputation to be key influential in the development of these advantageous partnerships, who in their turn benefit market actions and firm performance. Other authors have also highlighted the importance of reputation with other nonmarket actors such as Yoffie \& Bergeinstein (1985) and Dahan (2005). Dahan (2005) identified the public image and support of stakeholders as influential assets (p47).

Mahon et al. (2003) too discuss public image and stakeholder involvement, yet take a very unique approach to the social nonmarket arena. The authors adopt a social network perspective in an attempt to explore the function of nonmarket actions, in which distinct tools and competences arise such as issue scanning and stakeholder mapping. Due to their network level of analysis, Mahon et al. (2003) also identify new social assets such as the 
strategic position of a firm in a network and how this can be altered in order to seek more influence in the network.

Table 1. Nonmarket arenas, actions and assets

\begin{tabular}{|c|c|c|c|}
\hline Arena & Author & Actions & Assets \\
\hline \multirow{13}{*}{ 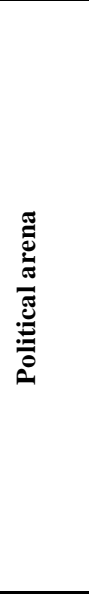 } & $\begin{array}{l}\text { Yoffie \& Bergenstein } \\
\text { (1985) }\end{array}$ & $\begin{array}{l}\text { Create coalitions with wide array of governmental } \\
\text { officials }\end{array}$ & $\begin{array}{l}\text { Governmental relations (resulting into an } \\
\text { political advantage) }\end{array}$ \\
\hline & Shaffer et al. (2000) & Employ frequent nonmarket actions & Political expertise \\
\hline & Vining et al. (2005) & $\begin{array}{l}\text { Scan/analyze industry including nonmarket } \\
\text { environment }\end{array}$ & $\begin{array}{l}\text { Ability to scan/analyze nonmarket environment } \\
\text { Governmental relations }\end{array}$ \\
\hline & & Identify governmental actions that (potentially) & \\
\hline & & affect the firm & \\
\hline & Hillman et al. (2003) & Employ people with political experience & Political experience \\
\hline & Frynas et al. (2005) & $\begin{array}{l}\text { Allow government intervention } \\
\text { Build and sustain governmental relations }\end{array}$ & $\begin{array}{l}\text { Strong governmental relations Ability to create } \\
\text { an FMA }\end{array}$ \\
\hline & & & Ability to erode a competitors' FMA \\
\hline & Dahan (2005) & Having a permanent office of representation or & Expertise \\
\hline & & consultants under contract & Relational resources (government) \\
\hline & & Embodying offices of trade associations & \\
\hline & Bonardi et al. (2005) & Employ frequent nonmarket actions & Honorable reputation \\
\hline & & Scan/analyze nonmarket environment & $\begin{array}{l}\text { Experience } \\
\text { Ability to scan/analyze the environment }\end{array}$ \\
\hline \multirow{10}{*}{ 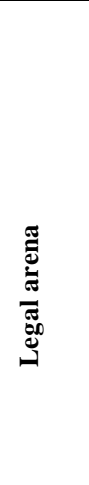 } & Baron (1997) & Initiate trade actions & Ability to create synergy between market and \\
\hline & & $\begin{array}{l}\text { Filing petition (under trade law) } \\
\text { Directing public and congressional attention to a } \\
\text { case }\end{array}$ & nonmarket strategies \\
\hline & Meznar \& Nigh & Using lobbyists to represent the firm's interests & Influence on the legis lative process \\
\hline & (1995) & Using trade association(s) to exert influence & Influence on the regulatory process \\
\hline & & & Ability to control the (nonmarket) environment \\
\hline & Lord (2000) & Use of external lobby experts & Expertise \\
\hline & Clougherty (2003) & Participating in testimonies before hearings of & Reputation \\
\hline & & government Dodies & $\begin{array}{l}\text { Influence on outcome of merger reviews and } \\
\text { antitrust policy }\end{array}$ \\
\hline & Hillman (2003) & Train employees to lobby for constituency & Influence on policy \\
\hline & & building & Ability to control the environment \\
\hline \multirow{18}{*}{ 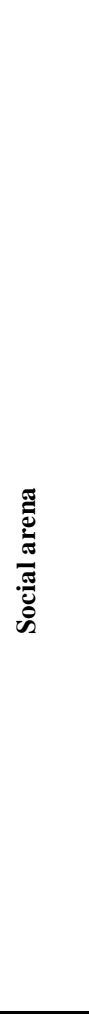 } & Usero \& & Employ frequent nonmarket actions such as & Legal expertise \\
\hline & Fernanández (2009) & $\begin{array}{l}\text { lawsuits, filing complaints with regulatory bodies } \\
\text { and making public accusations against rivals }\end{array}$ & Ability to erode a competitor's FMA \\
\hline & $\begin{array}{l}\text { Yoffie \& Bergenstein } \\
\text { (1985) }\end{array}$ & $\begin{array}{l}\text { Create coalitions with wide array of firms (socially } \\
\text { embedded working relations) }\end{array}$ & $\begin{array}{l}\text { Business environment focused on innovation } \\
\text { and learning }\end{array}$ \\
\hline & Baron (1995a) & $\begin{array}{l}\text { Employ non market actions that create a socially } \\
\text { responsible reputation }\end{array}$ & Reputation \\
\hline & $\begin{array}{l}\text { Meznar \& Nigh } \\
\text { (1995) }\end{array}$ & $\begin{array}{l}\text { Use of PR campaigns such as press releases and } \\
\text { community meetings } \\
\text { Advocacy advertising }\end{array}$ & Influence in a social network \\
\hline & Uzzi (1997) & Construct social arrangements and partnerships & $\begin{array}{l}\text { Better integration of market and nonmarket } \\
\text { strategies }\end{array}$ \\
\hline & & & Reputation \\
\hline & Kostova \& Zaheer & Engaging institutional relations & Decreased institutional distance \\
\hline & (1999) & Cooperating with institutions & $\begin{array}{l}\text { Ability to tailor nonmarket actions to specific } \\
\text { culture }\end{array}$ \\
\hline & Hillman (2003) & $\begin{array}{l}\text { Use of PR campaigns such as press releases and } \\
\text { community meetings }\end{array}$ & Influence in a social network \\
\hline & & Advocacy advertising & \\
\hline & Mahon et al. (2003) & Delineate nature and scope of network & Influence in a social network \\
\hline & & Identify core attributes of networks & Strong strategic position of a firm in a network \\
\hline & Dahan (2005) & Membership of standard committees & Reputation \\
\hline & & Interpersonal contacts with nonmarket actors & $\begin{array}{l}\text { Public image } \\
\text { Support of stakeholders }\end{array}$ \\
\hline & Hemphil (2006) & $\begin{array}{l}\text { Balance short-term nonmarket actions with } \\
\text { long-term reputation }\end{array}$ & Reputation \\
\hline & $\begin{array}{l}\text { Rodriguez et al. } \\
\text { (2006) }\end{array}$ & $\begin{array}{l}\text { Identify global CSR } \\
\text { Identify country-specific CSR }\end{array}$ & Ability to scan/analyze the environment \\
\hline & Tian \& Gao (2006) & Building organizational legitimacy & Reputation \\
\hline
\end{tabular}

An important contribution of Mahon et al. (2003) is their argument that the current demarcation between issue 
evolution affecting the firms' performance and stakeholder management is 'bad for practice" (p1 84), since they are often intertwined. In this, they specifically argue to directly link stakeholder management to firm performance. Meznar \& Nigh (1995) and Hillman (2003) suggest several tools for stakeholder management, such as influencing the public opinion and managing issues. They assert the use of PR campaigns such as press releases and community meetings. They also put forward advocacy advertising in the media on a several issue positions, as useful tools to influence (2003, p749).

All together, the various aspects of the social nonmarket arena discussed above, lead to the following third hypothesis:

H3: Knowledge and benefits accumulated from actions in the social arena of the nonmarket environment explain the positive contribution of social assets to firm performance.

\section{Methodology}

\subsection{Data Collection and Sample}

The unit of analysis is the object that will be the subject of the conclusion and ought to be mentioned in the research question (Hart, van Dijk, de Goede, Jansen \& Teunissen, 1998, p91). In this paper, the unit of analysis is the foreign owned firm (FOF).

According to Hair (2006), sample size can have a se vere effect on the estimation of the structural model and thus generalizability of the results. He suggests a minimum sample size of 100-200 when dealing with 5 constructs that have three indicators or more, as is the case in the model used in this thesis. He also points out the sensitivity of the technique when using a sample that is too large (2006, p740-742). However, "PLS is less sensitive to sample size considerations" (Hair, 2006, p878). Given the previous arguments, a sample size of 180 FOF can be considered sufficient to test the model using PLS.

The data was collected using a mail survey among FOF in the Netherlands. The survey starts with a few instructions and comprises two sections; Part A and B. Part A 'Background information' consists of questions regarding the origin of the subsidiary and the parent. Amongst others, data regarding firm performance and firm size are derived from this part. Other information such as current business activities and relationship with HQ can provide useful insights in the interpretation of research results and will be used in chapter 5, discussion.

Part B 'Institutional factors affecting business activities in the Netherlands' treats six different possible elements that affect business activities of the foreign owned subsidiary, namely European and Dutch regulatory factors, standards agencies factors, political factors, interest groups factors and media factors. However, Part B is not used in this thesis.

Part C 'Nonmarket strategies' is the main data source of the structural model and consists of 24 political, legal and social nonmarket actions that foreign owned subsidiaries can employ. They can be answered using a Likert scale from 1 (never) to continuously (5) and 1 open question that offers two options. Also, nonmarket action intent and direct market relations are asked for in order to be able to identify the answers given in the previous sections as pure nonmarket strategies. However, the data derived from these latter questions -although usefulwill not be used to analyze or estimate the model in this thesis, but can be used for interpretation objectives.

\subsection{Analysis Technique}

Partial Least Squares is an approach in the range of the various techniques that can be used when performing Structural Equation Modeling. The foundation of SEM can be found in factor analysis and multiple regression analysis, examining the "structure of interrelationships expressed in a series of equations" (Hair, 2006, p711). It provides room for measuring latent constructs who are difficult to empirically measure directly, which can be often found in social sciences and strategic management literature. According to Hair, "a latent construct [...] is a hypothesized and unobserved concept that can be represented by observable or measurable variables" (2006, p712). Indicators or manifest variables are used to measure the latent construct (or variable), such as firm performance. Apart from a different level of analysis, another advantage of SEM in general is that they allow studying theory and measures at the same time (Hulland, 1998, p195). This is specifically beneficial in the case of strategic management literature, in the sense that it forces researchers to be specific about their theories and can help to gain new insights (Hulland, 1998, p202). Conceptually, SEM offers an enormous advantage in the way it does not automatically give equal weight to any of the indicators (in this case, nonmarket actions). As discussed earlier, in previous empiric research linking nonmarket actions to firm performance, market actions are given equal weight (Schaffer et al. 2000; Usero \& Fernández, 2009). By using SEM, this study can provide insight into which market actions account for the largest influence on building nonmarket assets and how these assets individually contribute to firm performance. 
Defining individual constructs

As demonstrated in figure 1, multiple latent constructs are present in the structural model. This results in 4 constructs. Political nonmarket assets, legal nonmarket assets, social nonmarket assets are exogenous constructs caused by the indicators, along the lines of formative measurement theory, which will be discussed in the next section. The nonmarket assets are widely discussed in the theoretical framework and are defined as "the knowledge and benefits gained by the foreign owned firm from performing activities in a political, legal or social nonmarket arena". Firm performance is an endogenous, first order latent construct and the most important dependent variable in the model. According to Birkinshaw \& Morrison (1995), subsidiary (or firm) performance is a complex construct, considering that performance is relative to the goals set out by the parent company. Thus, for conceptual and statistical reasons, firm performance is measured by three different indicators; total sales growth, market share and profitability of the foreign owned firm.

Defining the measurement model

Apart from the constructs present in the model, table 2 also presents the indicators used to measure them. The theoretical justification as to why these indicators are hypothesized to influence firm performance is extensively discussed in chapter 2 and needs no repetition here.

However, prior to discussing the measurement model, a remark must be made why certain indicators have been chosen over others. The nonmarket actions used to measure these assets were chosen on three grounds. First, actions that have been mentioned by several authors (e.g. building governmental relations) were chosen, due to their stronger theoretical grounding of having an effect on firm performance. Secondly, an attempt was made to choose indicators that are relatively uneasy to imitate by others, as this potentially leads to a greater competitive advantage. Thirdly, actions that were unique to a specific arena (e.g. testimonies in expert hearings in the legal arena) have also been chosen. In this way, an attempt is made to combine the more structural, general assets that have a large potential to influence firm performance, with those that ensure the unidimensionality of the measured concepts. Noteworthy are also the choices as to direction of causality and to the number of indicators used. This is discussed next.

Table 2. Constructs and indicators

\begin{tabular}{lll}
\hline Variable & Construct & Indicators \\
\hline Exogenous & Political nonmarket assets & Partnerships to influence a political issue \\
& & Presence of firm members in political parties \\
& Employing people with political experience \\
& Interactions with local governments \\
& & Interactions with national governments \\
Exogenous & \multirow{2}{*}{ Legal nonmarket assets } & Testimonies in expert hearings \\
& & Employee training for trade unions participation \\
& & Hiring/contracting of PR external lobbyists \\
& & Challenge of government regulations \\
Exogenous & Social assets & Hiring/contracting of media experts \\
& & Building socially responsible reputation \\
& & Active cooperation with Dutch institutions \\
& & Ad-hoc cooperation with Dutch institutions \\
Endogenous & Firm performance & Market share \\
& & Total sales growth \\
& & Profitability \\
\hline
\end{tabular}

\section{Anal ysis and Results}

\subsection{Analysis of Bivariate Correlation}

Analysis of the bivariate correlation matrix in SPSS provides a first good representation of the correlation amongst the variables used to measure the latent variables in the structural model. In our model, most of the indicators have a significant ${ }^{1}$, positive correlation amongst each other, with an acceptable maximum of 0.591 (sig 0,00) between hiring PR specialists and hiring/contracting of media experts. Indicators ought to be removed

${ }^{1}$ At a 0.05 confidence interval level. 
when a correlation above 0.9 is found and conceptual overlap is clear (Cenfetelli \& Bassellier, 2009, p694). A perfect and therefore critical correlation of 1.0 (sig 0.00) was found between indicators hiring PR specialists and employee training for trade unions participation. Since there is no obvious theoretical overlap, neither of the indicators is removed yet, but will be kept in mind during the subsequent steps of the analysis.

A final point of consideration that can be derived from analysis of the correlation matrix is the significant positive correlation between only two indicators with any of the three performance indicators. All other bivariate correlations are either non-significant (in 34 cases) or significant, yet negative. This is the case with performance indicator profitability with market actions presence of firm members in political parties, employing people with political experience, employee training for trade unions participation and hiring PR specialists with a respective correlation of -0.268 (sig 0.003), -0.198 (sig 0.012), -0.160 (sig 0.48) and again -0.160 (sig 0.43). The performance indicator market share was additionally negatively correlated to presence of firm members in political parties with a correlation of -0.182 ( $\operatorname{sig} 0.022$ ).

Furthermore, after careful theoretical consideration that is substantiated by a negative bivariate correlation with all reflective indicators of the endogenous dependent variable- and a potential conceptual overlap, the indicators presence of firm members in political parties (tolerance 0.163; VIF 6.1374) and employing people with political experience (tolerance 0.150 ; VIF 6.6554) were deleted from the measurement model.

The software used for the path-modeling procedure is SmartPLS 2.0 (Ringle et al, 2005). This has been applied to measure the causal model for the effects nonmarket actions of Dutch foreign owned subsidiaries on the growth of nonmarket assets, which are theorized to enhance firm performance of the foreign owned firm. The causal model and empirical measurement results are illustrated in Figure 2.

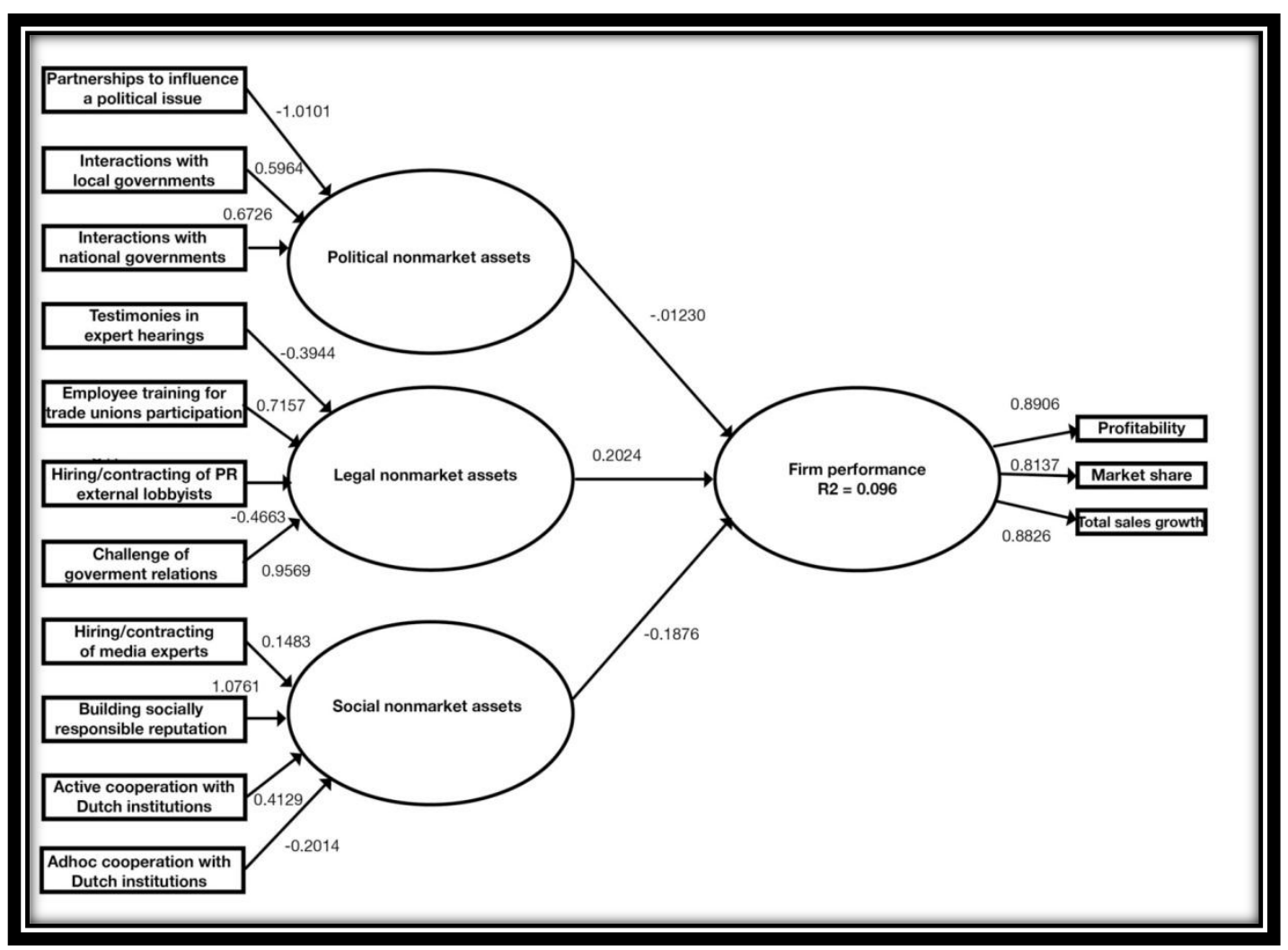

Figure 2. Measurement results for the structural equations model

\section{Evaluation of the reflective measurement model}

The assessment of reliability and validity measures is identified as the first out of three challenging methodological issues according to Hulland (1999). He identifies the following steps in assessing the adequacy of the reflective measurement model: individual item reliability, convergent validity and discriminant validity. These are discussed next.

The sole reflectively measured construct in this model is firm performance. The improved firm performance of a 
foreign owned subsidiary -due to the undertaking of nonmarket actions- is a latent variable that can be measured as a construct of the indicators market share, total sales growth and profitability. As a latent construct, the variable explains the variance of each indicator to great extent. The factor-loadings determine the power of the interrelations between firm performance and its indicators. When assessing the empirical results, all indicators of the reflective measurement model portray high values of 0.89 for profitability, 0.81 for market share and 0.88 for total sales growth. Any indicator with a loading above $>0.7$ is determined as good (Carmines \& Zeller, 1979), thus the manifest variables used for the reflective measurement of the latent dependent variable performance is substantiated.

An additional measure for the assessment of the reflective measurement model is the composite reliability. According to Chin (2010, this measure surpasses the reliability measure of Chronbach's Alpha in that it does not assume equal weights among indicators (Chin, 2010). The composite reliability is measured by $\rho c$ and has a value of 0,897158 . The $\rho c$ has to be $>0.6$ Chin (1998), thus the threshold is substantially met.

Lastly, reflective measurement models acquire the assessment of discriminant validity that ensures unidimensionality amongst constructs, for which the Average Variance Extracted measure (AVE) is used. However, since there is only one reflective measurement model in the structural model, the discriminant validity does not have to be reported (Chin, 1998; Hulland, 1999; Höck \& Ringle, 2006).

\section{Evaluation of the formative measurement model}

As discussed previously, the three latent exogenous variables in the structural model in this thesis are as discussed determined by formative measurement models. A test of significance (t-test) of the interrelations between the manifest variables and latent variables can be performed by applying bootstrapping procedures (Henseler et al, 2009).

All three variables used to measure the latent construct political nonmarket assets were found to be significant at either a 0.05 or 0.01 confidence interval level. In formative measurement, Cenfetelli \& Bassellier (2009) recommend reporting the absolute correlations as well since negative or low relative loadings do not exclude a substantial bivariate correlation between the indicator and the latent construct (2009, p697-698). The indicator partnerships to influence a political issue scored a relative loading of -1.010 (with an absolute loading of -0.3851). The indicator interactions with local governments has a loading of 0.5964 (0.5963). The indicator interactions with national governments was found to have a loading of $0.6726(0.4317)$.

The variables measuring the latent construct legal nonmarket assets were also found significant at either a 0.01 or 0.1 confidence interval level (see Table 1, Appendix D). The indicator testimonies in expert hearings has a loading of -0.3994 (0.0416), employee training for trade unions participation showed a loading of 0.7157 (0.5306), hiring/contracting of PR external lobbyists was found to have a loading of -0.4663 (0.1027) and lastly, challenge of government regulations reported a loading of 0.9568 (0.7155) onto the latent construct.

The third construct social nonmarket assets was also measured by four indicators, of which only building socially responsible reputations was significant at a 0.01 confidence interval level (see Table 1 , Appendix D). This variable reported a weight of 1.0761 (0.8230). The variables hiring/contracting of media experts, active cooperation with Dutch institutions and ad-hoc cooperation with Dutch institutions reported a loading of respectively $0.1482(-0.0908),-0.4129(-0.1681)$ and $-0.2014(-0.1560)$.

In summary, 8 out of 11 indicators measuring nonmarket assets were found to be significantly loading into their specific latent constructs. The obvious co-occurrence of negative and positive indicator weights could however be a sign of potential misspecification of the measurement model as set out by Cenfetelli \& Bassellier (2009). Possible causes are multicollinearity and the number of indicators (Cenfetelli \& Bassellier, 2009, p692-693).

\section{Evaluation of structural model}

The central criterion for evaluating the structural measurement model is the rate of reliability R2 of the latent endogenous variable firm performance, which has a value of 0.096. Thus, undertaking nonmarket actions in order to develop nonmarket assets as presented in this model, does not have a large explanatory power since only $9.6 \%$ of the change in firm performance is explained by these actions.

In the structural model, undertaking legal nonmarket actions results with a weight of 0.202 in legal nonmarket assets that influence the latent endogenous variable firm performance and its R2 of 0.096. Legal nonmarket assets result in the largest explanatory share of the three assets influencing firm performance. Thus, employee training for trade unions participation, hiring/contracting external lobbyists, challenge of government regulations and performing testimonies in expert hearings together result in a positive change in firm performance. However, both political as social nonmarket assets have a negative weight of respectively -0.123 and -0.188 . 
Thus, the rate of reliability $\mathrm{R} 2$ of the latent endogenous variable firm performance is substantially determined by legal nonmarket assets and only barely by political or social nonmarket assets. The significance of the interrelations between political assets and firm performance (weight of -0.123), legal assets and firm performance (weight of 0.202) and social assets and firm performance (weight of -0.188) have to be estimated. The bootstrapping procedure was applied which carried out t-tests to determine the significance of the relations between the latent endogenous and the latent exogenous variables. The results indicate that none of the latent variable relations are statistically significant with t-values all above the minimal critical level of $1.28^{2}$ (see Table 1, Appendix B).

Another criterion for the assessment of the structural model is the predictive relevance Q2, which can be measured using blindfolding procedures (Chin, 1998, p317). If this value is larger than zero, the latent exogenous variables have predictive relevance for the latent endogenous variable. In our structural equation model for foreign owned subsidiaries, the Q2 value of 0.7474 is clearly above zero (see Table 3, Appendix B). This means that the exogenous variables political nonmarket assets, legal nonmarket assets and social nonmarket assets have substantial predictive power in the structural model on the endogenous dependent variable firm performance. However, legal nonmarket assets have a predictive value of 1.2050 , which clearly meets the criterion of Chin (1998) of a value above zero for predictive relevance. In other words, the rate of reliability $\mathrm{R} 2$ of the latent endogenous variable firm performance is mainly determined by the latent exogenous variable legal nonmarket assets.

For reasons of simplicity, the main effects found in this chapter are summarized in Table 3.

Table 3. Summary of main effects

\begin{tabular}{ll}
\hline Reflective measurement model & All indicators were found significant at a 0.01 confidence interval level, and \\
& sufficiently measuring the latent construct firm performance (weights all $>0.7)$. \\
Formative measurement model & 8 out of 11 indicators were found significant at a $0.01,0.05$ or 0.1 confidence \\
interval level. & \\
The indicators hiring/contracting of media experts, active cooperation with Dutch & institutions and ad-hoc cooperation with Dutch institutions were found to be \\
insignificantly measuring the latent construct social nonmarket assets. & R2 of firm performance $=0.096$ which can be classified as small. \\
Q2 of firm performance $=0.747$ which is substantial, thus the model has \\
substantial predictive relevance. \\
All structural paths were found insignificant. \\
The predictive relevance and effect size of legal nonmarket assets were most \\
influential on the R2 and prediction of firmperformance. \\
Both social nonmarket assets as political nonmarket assets were found to have a \\
small effect size and predictive relevance.
\end{tabular}

\section{Discussion and Conclusions}

First, the measurement model of the exogenous latent variable political nonmarket assets is discussed. Both interactions with local governments as interactions with national governments were found significant, with a loading of respectively $0.5964(0.5963)$ and $0.6726(0.4317)$. Given the wide theoretical foundation for this assumption, the outcome was not surprising. The empirical confirmation of this relation shows that these two nonmarket assets are potential structural indicators for political nonmarket activity. This finding contributes to the scale development in nonmarket research. The indicator partnerships to influence a political issue was found to be significant, yet with a negative path coefficient of -1.010 (with an absolute loading of -0.3851). Indicators with a negative path coefficient and corresponding negative bi variate loading, are advised to be deleted from the scale (Cenfetelli \& Bassellier, 2009, p696).

In conclusion, interactions with local governments and interactions with national governments were found to be successful to measure political nonmarket assets; the latter relation was a bit stronger than the first. However, partnerships to influence a political issue cannot be regarded as a useful indicator for political nonmarket assets. This finding corresponds with the suspicions that were raised in the uni variate and bi variate analysis prior to the PLS-analysis.

\section{Formative measurement of legal nonmarket assets}

Secondly, the measurement model of the exogenous latent variable legal nonmarket is examined. All indicators were found to be statistically significant, yet with different loadings. The indicators employee training for trade unions participation and challenge of government relations presented with a respective loading of 0.7157

${ }^{2}$ At a confidence interval level of 0.1 
(0.5306) and $0.9568(0.7155)$. This leads to the conclusion that both indicators are suitable indicators to measure the latent variable legal nonmarket assets.

However, the almost perfect loading of 0.9568 does raise some suspicions regarding the reliability of this measurement scale. An explanation can be found in the other two indicators that were used to measure legal nonmarket assets. The indicators hiring/contracting of PR external lobbyists and testimonies in expert hearings were found significant, yet with a negative loading of respectively $-0.4663(0.1027)$ and $-0.3994(0.0416)$,

Cenfetelli \& Bassellier provide several steps to analyze the co-occurrence of negative and positive indicators weights. The first step is to analyze the possibility of suppressor effects. Suppression is "a variable which increases the predictive validity of another variable (or set of variables) by its inclusion in a regression equation" (MacKinnon et al, 2000). After further analysis, a supressor effect was indeed found caused by the variable hiring/contracting of $P R$ external lobbyists. Deleting this variable turned all other remaining variables into statistically significant, positive loadings, including the formerly negatively loaded testimonies in expert hearings. This variable can thus be retained for further scale development, given its positive bivariate loading and altered positive significant after deletion of the suppressor (Cenfetelli \& Bassellier, 2009, p696), In the case of suppressor behavior, variables must be deleted from the measurement scale (Cenfetelli \& Bassellier, 2009, p696),

In conclusion, the indicators employee training for trade unions participation and challenge of governmental relations are suited indicators to measure political nonmarket assets. The indicator testimonies in expert hearings was under the influence of a suppressor effect and can be retained for further research and scale development. The indicator hiring/contracting of PR external lobbyists acted as a suppressor variable and a re-use of this indicator in a similar model is ill advised.

\section{Formative measurement of social nonmarket assets}

Thirdly, the measurement model of the exogenous latent variable social nonmarket assets is treated. The indicator building socially responsible reputations was found significant with a weight of $1.0761(0.8230)$. However, the perfect loading $(>1)$ indicates a problem that is potentially caused by other indicators.

The existence of negative path loadings and absence of significance in all remaining indicators measuring social nonmarket assets is another sign of disturbance. After careful analysis, another suppressor effect was found caused by the indicator building socially responsible reputations. Deleting this variable from the analysis turned the path loadings of the remaining three indicator into positive ones, of which two are statistically significant; hiring/contracting of media experts and ad-hoc cooperation with Dutch institutes.

In conclusion, the indicator building socially responsible reputations acted as a suppressor effect and re-use of this indicator in a similar model is ill advised. The indicators hiring/contracting of media experts and ad-hoc cooperation with Dutch institutes were found significant and positively loading on nonmarket legal assets after the deletion of the suppressor effect. The indicator active cooperation with Dutch institutions was found insignificant and should be removed from the scale according to the results. However, given the strong theoretical foundation for including this indicator, the relative low predictive relevance of the model and the overall instable research results, a definite exclusion of this indicator in nonmarket research is not advised.

\section{Recommendations}

The existing research on the effect of nonmarket activity is promising and any awareness of the dynamics in this field is valuable, especially those that benefit from amicable relations in the institutional environment. Foreign owned firms must be aware of the potential benefits and opportunities that lie in this area of expertise. Apart from these general managerial recommendations that are mainly based on the literature study that was performed in this thesis, the main focus of this paragraph is to explicate the scientific recommendations.

The most important recommendation for future research builds upon the learning theories that were used in this thesis, towards an overall, corporate nonmarket capability. Vining et al. (2005) recognize the potential of a corporate nonmarket capability. In addition to that, Bonardi et al. (2005), state that "internal resources and capabilities are important determinant of success in the political marketplace". They argue that capabilities are specifically advantageous for political markets, since higher transactions costs arise than in economic markets and that a nonmarket capability can aid to lower these transaction costs (p1214). They conclude that future research ought to be focused at the development of nonmarket capabilities (2005, p411). An advantage of developing a capability is that they enable firms to develop new strategic assets more quickly and more efficiently than their competitors (Teece et al., 1998, p39-40). This is specifically beneficial in a nonmarket environment that can be characterized as and rapidly changing, due to changing political climate and 
corresponding regulatory environment (Bonardi et al. 2006, p 1217). In addition to that, I argue that globalization and the more intense use of the Internet, eroding borders of national and even continental borders, will only add more speed to the changes in the nonmarket environment.

As Baron (1995a) pointed out, many nonmarket actions are aimed at the greater goal of enhancing market performance or creating new market opportunities (p57). I assert that in the act of combining these two environments lies a specific nonmarket capability that can be particularly advantageous for foreign owned firms. Although domestic firms posses more knowledge of the host environment institutional arena, it is plausible they have less experience in dealing with nonmarket dynamics in general. Aided by the corporate firm -or the parentforeign owned subsidiaries can learn from other subsidiaries and use this knowledge to reduce the liability of foreignness towards domestic firms in host environments.

A second future area of research is linked to the way that firms build such a capability. King and Tucci (2002) already appointed managers an important role in the transference of experience in the learning process. According to them, more experience broadened the scope of choices available to managers and facilitated the recognition of advantageous opportunities for firms (p181-p183). This can lead to more knowledge of nonmarket activity in general, aid the development of a firm-specific nonmarket capability, gain more insight in the specific circumstances under which nonmarket activity is most beneficial to firm performance. Exactly which type of influence managers have in this process and how they can be instructed to facilitate this process can be a valuable field of future research, not only in the development of a specific nonmarket capability but in capability development in general.

A final recommendation is closely linked to one of the limitations of this study; the object of research. The home market of the Netherlands is rather small and could be of small value to the firm performance of the parent firm of the foreign owned subsidiary. A strong recommendation is to repeat this study while take into account the importance of nonmarket activity to the firm, preferably in a country that has a larger home market. It is also possible to define the home market not on a national but on a supranational level, crossing national borders. According to Vining et al. (2005), these venues have grown in weight given 1) the globalization of business-related issues such as environment and health, 2) the growth of global and regional trade regimes such as the World Trade Association, North American Free Trade Agreement, Asia-Pacific Economic Cooperation and European Union), and 3) the absolute growth of multinational firms.

\section{References}

Aggarwal, V. K. (2001). Corporate Market and Nonmarket Strategies in Asia: A Conceptual Framework. Business and Politics, 3(2), 89-108. https://doi.org/10.2202/1469-3569.1020

Argyris, C. (1977). Double loop learning in organizations. Harvard Business Review. September-October: $115-125$.

Argyris, C., \& Schon, D. (1978). Organizational Learning: A theory of action perspective. Reading, MA: Addison-Wesley.

Baron, D. P. (1995). Integrated Strategy: Market and Nonmarket Components. California Management Review, 37(2), 47-66. https://doi.org/10.2307/41165788

Baron, D. P. (1995). The Nonmarket Strategy System. Sloan Management Review, 37(1), 73-85.

Baron, D. P. (1997). Integrated Strategy and International Trade Disputes: The Kodak-Fujifilm Case. Journal of Economics \& Management Strategy, 6(2), 291-346. https://doi.org/10.1162/105864097567110

Baron, D. P. (2003). Business and its environment. Upper Saddle River, NJ: Prentice Hall.

Birkenshaw, J., \& Hood, N. (1998). Multinational Subsidiary Evolution: Capability and Charter Change in Foreign-owned Subsidiary Companies. Academy of Management Review, 23(4), 773-795.

Blumentritt, T., \& Nigh, D. (2002). The Integration of Subsidiary Political Activities in Multinational Corporations. Journal of International Business Studies, 33(1), 57-77. https://doi.org/10.1057/palgrave.jibs.8491005

Bodewyn, J. J. (2003). Understanding and Advancing the Concept of "Nonmarket". Business Society, 42, 297-327. https://doi.org/10.1177/0007650303257504

Bollen, K., \& Lennox, R. (1991). Conventional wisdom on measurement: A structuralperspective. Psychological Bulletin, 110(2), 305-314. https://doi.org/10.1037/0033-2909.110.2.305

Bonardi, J. P., Holburn, G. L. F., \& Vanden, B. R.G. (2006). Nonmarket Strategy Performance: Evidence from 
U.S. Electric Utilities. Academy of Management Journal, 49(6), 1209-1228. https://doi.org/10.5465/AMJ.2006.23478676

Bonardi, J. P., Jillman, A. J., Keim, G. D. (2005). The Attractiveness of Political Markets: Implications for Firm Strategy. Academy of Management Review, 30(2), 397-413. https://doi.org/10.5465/AMR.2005.16387895

Cenfetelli, R. T., \& Bassellier, G. (2009). Interpretation of Formative Measurement in Information System Research. MIS Quarterly, 33(4), 689-707. https://doi.org/10.2307/20650323

Chandler, A. D. (1992). Organisational Capabilities and the Economic History of the Industrial Enterprise. Journal of Economic Perspective, 6(3), 79-100. https://doi.org/10.1257/jep.6.3.79

Clougherty, J. A. (2003). Nonmarket Strategy for Merger Reviews. Business and Society, 42(1), 115-140. https://doi.org/10.1177/0007650302250513

Dahan, N. (2005). A Contribution to the Conceptualization of Political Resources Utilized in Corporate Political Action. Journal of Public Affairs, 5(1), 43-54. https://doi.org/10.1002/pa.4

Diamantopoulos, A., Rielfer, P., \& Roth, K. P. (2008). Advancing Formative Measurement Models. Journal of Business Research, 61(12), 1203-1218. https://doi.org/10.1016/j.jbusres.2008.01.009

Fornell, C., \& Bookstein, F. L. (1982). Two Structural Equation Models: LISREL and PLS Applied to Customer Exit-Voice Theory. Journal of Marketing Research, 19(4), 440-452. https://doi.org/10.2307/3151718

Frynas, J. G., Mellahi, M., \& Pigman, G. A. (2006). First Mover Advantages in International Business and Firm-specific Political Resources. Strategic Management Journal, 27(4), 321-345. https://doi.org/10.1002/smj.519

Getz, K. A. (2001). Public Affairs and Political Strategy: Theoretical Foundations. Journal of Public Affairs, 1(4), 305-329. https://doi.org/10.1002/pa.77

Govindarajan, V., \& Gupta, A. (2000). Analysis of the Emerging Global Arena. European Management Journal, 18(3), 274-284. https://doi.org/10.1016/S0263-2373(00)00009-8

Hair, J. F., Black, W. C., Babin, B. J., Andersom, R. E., \& Tatham, R. L. (2005). Multivariate Data Analysis. Pearson Prentice Hall: New Jersey.

Hart, H. 't, Dijk, J. van, Goede, M. de, Jansen, W., \& Teunissen, J. (1998). Onderzoeksmethoden. 6e druk. Boom: Amsterdam.

He, Y. (2006). How Firms Integrate Nonmarket Strategy with Market STrtaegy: Evidence from Mainland of China. Journal of American Academy of Business, 10(1), 357-361.

Hemphil, T. A. (2006). Corporate Internal Investigations: Balancing Firm Social Reputation with Board Fiduciary Responsibility. Corporate Governance, 6(5), 635-642. https://doi.org/10.1108/14720700610706117

Henseler, J., Ringle, C. M., \& Sinkovics, R. R. (2009). The Use of Partial Least Square Modeling in International Marketing. Advances in International Marketing, 20, 277-319. https://doi.org/10.1108/S1474-7979(2009)0000020014

Hillman, A. J., \& Hitt, M. A. (1999). Corporate Political Strategy Formulation: A Model of Approach, Participation, and Strategy Decisions. The Academy of Management Review, 24(4), 825-842.

Hillman, A. J., Keim, G. D., \& Schulder, D. (2004). Corporate Political Activity: AReview and Research Agenda. Journal of Management, 30(6), 837-857. https://doi.org/10.1016/j.jm.2004.06.003

Hitt, M. A., Keats, B. W., \& DeMarie, S. M. (1998). Navigating in the New Competitive Landscape: Building Strategic Flexibility and Competitive Advantage in the $21^{\text {s }}$ Century. Academy of Management Executive, 12(4), 22-42. https://doi.org/10.5465/AME.1998.1333922

Höck, M., \& Ringle, C. M. (2006). Strategic networks in the software industry: An empirical analysis of the value continuum. Online document: http://www.fim-unihh.de/IFSAM06.pdf, retrieved on 11-01-2011.

Hulland, J. (1999). Use of Partial Least Squares (PLS) in Strategic Management Research: A Review of Four Recent Studies. Strategic Management Journal, 20(2), 195-204. https://doi.org/10.1002/(SICI)1097-0266(199902)20:2<195::AID-SMJ13>3.0.CO;2-7

Hymer, S. (1976), The international operations of national firms: A study of direct investment, MIT Press, Cambridge, MA. 
Jarvis, C. B., Mackenzie, S. B., \& Podsakoff, P. M. (2003). A Critical Review of Construct Indicators and Measurement Model Misspecification in Marketing and Consumer Research. The Journal of Consumer Research, 30(2), 199-218. https://doi.org/10.1086/376806

Jones, M. T., \& Kunz, P. (2005). Competitive Advantage Through Nonmarket Strategy: Lessons from the Baywatch Experience. The Business Review, 3(2), 271-282.

Kale, P., \& Singh, H. (2007). Building Firm Capabilities Through Learning: The Role of the Alliance Learning Process in Alliance Capability and Firm-Level Alliance Success. Strategic Management Journa, 28(10), 981-1000. https://doi.org/10.1002/smj.616

King, A. A., \& Tucci, C. L. (2002). Incumbent Entry into New Market Niches: The Role of Experience and Managerial Choice in the Creation of Dynamic Capabilities. Management Science, 48(2), 171-186. https://doi.org/10.1287/mnsc.48.2.171.253

Kogut, B., \& Kulatilaka, N. (1994). Options Thinking and Platform Investments: Investing in Opportunity. California Management Review, 36(2), 200-216. https://doi.org/10.2307/41165744

Korzilius, H. (2000). De kern van survey-onderzoek. Van Gorcum \& Comp: Assen.

Levy, D. L., \& Egan, D. (2003). A Neo-Gramscian Approach to Corporate Political Strategy: Conflict and Accomodation in the Climate Change Negotiations. Journal of Management Studies, 40(4), 803-827. https://doi.org/10.1111/1467-6486.00361

Ma, H. (2004). Toward Global Competitive Advantage. Creation, Competition, Cooperation and Co-option. Management Decision, 42(7), 907-924. https://doi.org/10.1108/00251740410550961

MacKinnon, D. P., Krull, J. L., \& Lockwood, C. M. (2000). Equicalence of the Mediation,Confounding and Supression Effect. Prevention Science, 1(4), 173-181. https://doi.org/10.1023/A:1026595011371

Mahon, J. F., Heugens, P. P. M. A. R., \& Lamertz, K. (2003). Social Networks and Non-market Strategy. Journal of Public Affairs, 4(2), 170-189. https://doi.org/10.1002/pa.179

March, J. G., Sproull, L. S., \& Tamuz, M. (1991). Learning from samples of one or fewer. Organization Science 2, 1-13. https://doi.org/10.1287/orsc.2.1.1

Miller, K. D. (1992). A Framework for Integrated Risk Management in International Business. Journal of International Business Studies, 23(2), 311-331. https://doi.org/10.1057/palgrave.jibs.8490270

Miller, S. R., \& Parkhe, A. (2002). Is There a Liability of Foreignness in Global Banking? An Empirical Test of Banks' x-efficiency. Strategic Management Journal, 23(1), 55-75. https://doi.org/10.1002/smj.212

Miller, S. R., \& Richards, M. (2002). Liability of Foreignness and Membership in a Regional Economic Group: Analysis of the European Union. Journal of International Management, 8(3), 323-337. https://doi.org/10.1016/S1075-4253(02)00071-6

Rodriguez, P., Siegel, D. S., Hillman, A., \& Eden, L. (2006). Three Lenses on the Multinational Enterprise: Politics, Corruption, and Corporate Social Responsibility. Academy of International Business, 37, 733-746. https://doi.org/10.1057/palgrave.jibs.8400229

Schuler, D., Rehbein, K., \& Kramer, R. (2002). Pursuing Strategic Advantage through Political Means: A Multivariate Approach. Academy of Management Journal, 45(3), 659-672. https://doi.org/10.2307/3069303

Shaffer, B., Quasney, T. J., \& Grimm, C. M. (2000). Firm Level Performance Implications of Nonmarket Actions. Business \& Society, 39(2), 126-142. https://doi.org/10.1177/000765030003900202

Teece, D., \& Pisano, G. (1994). The Dynamic Capabilities of Firms: An Introduction. Industrial and Corporate Change, 3(3), 537-556. https://doi.org/10.1093/icc/3.3.537-a

Teece, D., Pisano, G., \& Shuen, A. (1997). Dynamic Capabilities and Strategic Management. Strategic Management Journal, 18(7), 509-533. https://doi.org/10.1002/(SICI)1097-0266(199708)18:7<509::AID-SMJ882>3.0.CO;2-Z

Tian, Z., \& Gao, H. (2006). Managing Corporate Legitimacy: Nonmarket Strategies of Chinese Firms. The Journal of American Acadamy of Business, 10(1), 97-101.

Usero, B., \& Fernández, Z. (2009). First Come, First Served: How Market and Nonmarket Actions Influence Pioneer Market Share. Journal of Business Research, 62(11), 1139-1145. https://doi.org/10.1016/j.jbusres.2008.07.005 
Vining, A. R., Shapiro, D. M., \& Borges, B. (2005). Building the Firm's Political (Lobbying) Strategy. Journal of Public Affairs, 5, 150-175. https://doi.org/10.1002/pa.17

Voinea, C. L., \& Kranenburg, van H. (2009). The Influence of Non-market Host Institutions on Foreign Owned Firms. AIB 2009 Conference, San Diego.

Windsor, D. (2001). Public Affairs, Issues Management, and Political Strategy: Opportunities, Obstacles and Caveats. Journal of Public Affairs, 1(4), 382-415. https://doi.org/10.1002/pa.83

Zaheer, S. (1995). Overcoming the liability of foreignness. Academy of Management Journal, 38(2), 34-63. https://doi.org/10.2307/256683

Zaheer, S. (2002). The liability of foreigness, redux; a commentary. Journal of International Management, 8 , 351-358. https://doi.org/10.1016/S1075-4253(02)00070-4

\section{Copyrights}

Copyright for this article is retained by the author(s), with first publication rights granted to the journal.

This is an open-access article distributed under the terms and conditions of the Creative Commons Attribution license (http://creativecommons.org/licenses/by/4.0/). 